\title{
Evaluation of marginal leakage of bulk fill flowable composite resin filling with different curing time using micro-computed tomography technology
}

\author{
Eun-Ji Kim', Kyu-Bok Lee², Myoung-Uk Jin* \\ 'Department of Conservative Dentistry, School of Dentistry, Kyungpook National University, Republic of Korea \\ ${ }^{2}$ Department of Prosthodontics, School of Dentistry, A3DI, Kyungpook National University, Republic of Korea
}

Purpose: To evaluate marginal leakage of bulk fill flowable composite resin filling with different curing time by using microcomputed tomography technology. Materials and Methods: 30 previously extracted human molars were randomly divided into 6 groups based upon restorative system and different curing time. Class II cavities (vertical slot cavities) were prepared. An individual metallic matrix was used to build up the proximal wall. The SonicFill or Surefil SDR flow was inserted into the preparation by using 1 bulk increment, followed by light polymerization for different curing times. The different exposure times were 20, 40, and 60 seconds. All specimens were submitted to 5,000 thermal cycles for artificial aging. Micro-CT scanning was performed by using SkyScan 1272. One evaluator assessed microleakage of silver nitrated solution at the resin-dentin interface. The 3D image of each leakage around the restoration was reconstructed with CT-Analyser V.1.14.4. The leakage was analyzed with the Mann-Whitney test. Results: Significant differences were observed between the light curing times, but no significant differences were found between the bulk fill composite resins. Increasing in the photoactivation time resulted in greater microleakage in all the experimental groups. Those subjected to 60 seconds of light curing showed higher microleakage means than those exposed for 20 seconds and 40 seconds. Conclusion: Increasing the photoactivation time is factor that may increase marginal microlekage of the bulk fill composite resins. Further, micro-CT can nondestructively detect leakage around the resin composite restoration in three dimensions. (J Dent Rehabil Appl Sci 2016;32(3):184-93)

Key words: marginal leakage; bulk fill; curing time; micro-computed tomography

\section{Introduction}

Light-cured resin composites have good mechanical properties, but polymerization shrinkage and shrinkage stress, which lead to internal microcrack, gap formation, marginal microleakage, ${ }^{1}$ are major limitations of composite resin materials. Managing the polymerization shrinkage stress of the composite

*Correspondence to: Myoung-Uk Jin

Professor, Department of Conservative Dentistry, School of Dentistry, Kyungpook National University, Dalgubeol-daero 2177, Jung-gu, Daegu, 41940, Republic of Korea Tel: +82-53-600-7623, Fax: +82-53-426-8958, E-mail: musljin@knu.ac.kr

Received: August 22, 2016/Last Revision: August 22, 2016/Accepted: September 13, 2016 resin material is important to ensure adequate marginal integrity and, therefore, the long-term stability of the restoration.

Recently, bulk fill composites have been more widely used because materials with improved curing, ${ }^{2}$ controlled polymerization contraction stresses, 3,4 and reduced cuspal deflection ${ }^{5}$ have been developed. Clinical recommendations suggest that placing these

CopyrightC 2016 The Korean Academy of Stomatognathic Function and Occlusion. (c) It is identical to Creative Commons Non-Commercial License. 
in 4-mm bulk increments, resulting in adequate polymerization. Bulk filling a cavity reduces some of the technical disadvantages associated with layering conventional composite resins, such as the incorporation of contamination or voids between the layers, and improves the chairside efficiency. ${ }^{6}$

The potential for increased contraction stress and inadequate cure depth are the major remaining concerns when curing bulk increments. ${ }^{7}$ Although several previous reports have suggested that this is an acceptable technique, ${ }^{2,48-10}$ others have suggested that bulk filling may produce undercured resin composites. ${ }^{11-13}$

Light-cured resin composites require adequate light exposure in order to achieve a proper degree of conversion and good physical properties. This is because the amount of free radical production is directly proportional to the amount of absorbed light irradiance. At the bottom of the cavity, the light intensity is insufficient for initiation of polymerization. ${ }^{14}$ Thus, at an increased exposure time, more light will consequently reach the deeper layer at the beginning of irradiation.

The curing time plays a crucial role in determining the stresses produced during the contraction of dental composites. The mechanical properties of the material formed are superior when the number of monomers converted in the polymers is larger. ${ }^{15,16}$ However, as the degree of conversion is increased, the volumetric shrinkage is also increased. ${ }^{17}$ High intensity light curing produces high hardness values as well as high shrinkage. Therefore, it is important to balance both of these effects by choosing the proper curing time. ${ }^{18}$

The advisability of rapid photocuring and bulk filling as an option for shortening the chairside time needs to be examined. However, this topic requires further exploration because few studies have investigated the interaction between marginal leakage and the irradiation time in bulk fill flowable composite resins.

Lately micro-CT analysis has been used as a reliable alternative to the conventional sectioning method for evaluating marginal leakage. To our knowledge, only a few previous investigations comparatively evaluated microleakage by using micro-CT.

Therefore, the purpose of this study was to evaluate the marginal leakage of bulk fill flowable composite resin filling with different time by using microcomputed tomography technology. The hypothesis of this study was that the increasing the light curing time would affect the microleakage of the bulk fill flowable composite resin.

\section{Materials and Methods}

\section{Tooth selection}

A total of 30 previously extracted human molars were selected. The calculus, soft tissue, and other tooth debris were cleaned and the teeth were stored in thymol solution $(0.1 \%)$ and saline until use. The root base was embedded with self-curing acrylic resin.

\section{Sample preparation}

The design of the experimental groups was based on the following factors: 1) restorative system (SonicFill and SureFil SDR flow) and 2) different curing time (20 seconds, 40 seconds, and 60 seconds). The groups are described in Table 1.

Class II cavities (vertical slot cavities) in human molars were prepared by using methods modified from Dewaele and others. ${ }^{19}$ The cavities were prepared under water cooling in the approximal surfaces of the molars, with the following dimensions $( \pm 0.5$ $\mathrm{mm})$ : width, $4 \mathrm{~mm}$; height, $4 \mathrm{~mm}$; depth, $2 \mathrm{~mm}$. The gingival floor was measured, $4.0 \mathrm{~mm}$ gingivally, locat-

Table 1. Group descriptions

\begin{tabular}{ccc}
\hline Group & Bulk fill composite & Curing time \\
\hline Group 1 & & 20 seconds \\
Group 2 & SonicFill & 40 seconds \\
Group 3 & & 60 seconds \\
Group 4 & & 20 seconds \\
Group 5 & SureFil SDR flow & 40 seconds \\
Group 6 & & 60 seconds \\
\hline
\end{tabular}


ed slightly occlusal and/or apical in proximity to the cementoenamel junction (CEJ), depending upon the proximal surface anatomy of each tooth. The dimensions of the cavities were verified with a periodontal probe.

A new bur was used for each cavity preparation. One operator performed all cavity preparations. Subsequently, the teeth were then randomly divided into 6 groups based upon the restorative system and curing time. The materials and light curing units utilized in this study are described in Table 2 and Table 3.

An individual metallic matrix was used to build up the proximal wall. The cavity was conditioned by using 37.5\% phosphoric acid gel etchant (Kerr Corporation, Orange, USA) for 15 seconds. Optibond Solo Plus adhesive agent (Kerr Corporation) was applied to the cavity, and followed by light polymerization for 20 seconds.
SonicFill composite system (Kerr Corporation) and SureFil SDR flow (Dentsply International, Milford, USA) was inserted into the cavity by using 1 bulk increment (4-mm thickness), followed by light polymerization for the specified curing time (20 seconds, 40 seconds, or 60 seconds). Light irradiation was performed by placing the light tip directly on the top of the resin with a 0 -mm distance.

The SonicFill was inserted into the cavity by using the SonicFill handpiece (Kavo, Biberach, Germany). The SonicFill handpiece was used to dispense automatically the rheologically matched filling materials that are contained in the SonicFill unidose tips into the cavity by the action of sound and pressure under a frequency of $5-6 \mathrm{kHz}$.

The curing unit was a Bluephase 20i (Ivoclar Vivadent, Schaan, Liechtenstein) with a light intensity of $1200 \mathrm{~mW} / \mathrm{cm}^{2}$.

Table 2. Materials used in this study

\begin{tabular}{|c|c|c|c|}
\hline Material & Type & Composition & Description \\
\hline $\begin{array}{l}\text { Gel Etchant } \\
\text { (Kerr Corporation, } \\
\text { Orange, USA) }\end{array}$ & $\begin{array}{c}37.5 \% \\
\text { phosphoric acid }\end{array}$ & $37.5 \%$ orthophosphoric acid, silica thickener & \\
\hline $\begin{array}{l}\text { Optibond Solo Plus } \\
\text { (Kerr Corporation, } \\
\text { Orange, USA) }\end{array}$ & $\begin{array}{l}\text { Light-cure total-etch } \\
\text { adhesive bonding } \\
\text { system }\end{array}$ & $\begin{array}{c}\text { Primer : HEMA, GPDM, PAMM, ethanol, } \\
\text { water, photo initiator } \\
\text { Adhesive : TEGDMA, UDMA, HEMA, } \\
\text { Bis-GMA, filler, photo initiator }\end{array}$ & \\
\hline $\begin{array}{l}\text { SonicFill } \\
\text { (Kerr Corporation, } \\
\text { Orange, USA) }\end{array}$ & $\begin{array}{l}\text { Sonic flowable bulk } \\
\text { fill composite }\end{array}$ & $\begin{array}{l}\text { Bis-GMA, TEGDMA, EBPDMA, silica, } \\
\text { glass, oxide } \\
\text { (filler content : } 83.5 \mathrm{wt}^{\mathrm{t}} \% \text { / } 69 \mathrm{vol} \% \text { ) }\end{array}$ & $\begin{array}{l}\text { Low-shrinkage composite } \\
\text { that allows the curing of } \\
\text { layers up to } 5 \mathrm{~mm} \text { thick }\end{array}$ \\
\hline $\begin{array}{l}\text { SureFil SDR flow } \\
\text { (Dentsply International, } \\
\text { Milford, USA) }\end{array}$ & $\begin{array}{l}\text { Flowable bulk } \\
\text { fill composite }\end{array}$ & $\begin{array}{l}\text { SDR patented UDMA, TEGDMA, } \\
\text { EBPDMA, barium and strontium alumino- } \\
\text { fluoro-silicate glass } \\
\text { (filler content : } 68 \mathrm{wt} \% \text { / } 45 \mathrm{vol} \% \text { ) }\end{array}$ & $\begin{array}{l}\text { Flowable composite base } \\
\text { material that allows the } \\
\text { curing of layers up to } 4 \\
\text { mm thick }\end{array}$ \\
\hline
\end{tabular}

HEMA, 2-Hydroxyethyl methacrylate; GPDM, glycerophosphoric acid dimethacrylate; PAMM, phthalic acid monomethacrylate; TEGDMA, triethyleneglycol dimethacrylate; UDMA, urethane dimethacrylate; Bis-GMA, bisphenol glycidyl methacrylate; EBPDMA, ethoxylated bisphenolA-dimethacrylate.

Table 3. Light curing unit used in this study

\begin{tabular}{cccc}
\hline Light curing unit & Type & Light intensity & Tip \\
\hline Bluephase 20i (Ivoclar Vivadent, Schaan, Liechtenstein) & LED & $1,200 \mathrm{~mW} / \mathrm{cm}^{2}$ & $8 \mathrm{~mm}$ \\
\hline
\end{tabular}

LED, Light emitting diode. 


\section{Aging procedure}

After the restorative procedures, all samples were artificially aged using thermal cycling for 24 hours. The specimens were thermocycled for 5,000 cycles in water baths between $5 \pm 2{ }^{\circ} \mathrm{C}$ and $55 \pm 2^{\circ} \mathrm{C}$ at a dwell time of 30 seconds in each bath and a transfer time of 5 seconds between baths.

\section{Silver nitrate immersion}

The entire tooth surface was covered with 2 layers of nail varnish within $1 \mathrm{~mm}$ of the bonded interface. In order to allow the varnish to dry, the specimens were left undisturbed for 1 day.

Subsequently, the teeth were immersed in a $50 \%$ weight/weight silver nitrate aqueous solution for 24 hours at room temperature. The silver-impregnated teeth were thoroughly rinsed with distilled water, placed into a photo-developing solution for 8 hours, and rinsed again with water.

\section{Micro-CT}

After being placed and fixed in the specimen holder, each tooth was scanned individually by using micro-CT at a resolution of $12 \mu \mathrm{m}$.
Micro-CT scanning was performed by using the SkyScan 1272 (Bruker, Kontich, Belgium). The settings of the micro-focus $\mathrm{X}$-ray source were as follows: $80 \mathrm{kV}, 125 \mu \mathrm{A}, 1-\mathrm{mm}$ thick aluminum plate filter, and $0.4^{\circ}$ rotation step with $180^{\circ}$ rotation.

The cross-sections were collected by sample and the raw data were converted to 16-bit-mapped image film with a resolution of $1,632 \times 1,092$ pixels. NRecon version 1.6.1 software (Bruker) was used for reconstruction of all images.

\section{Microleakage assessment}

Microleakage of the silver nitrate solution at the resin-dentin interface was assessed by one evaluator. The 3D image of each leakage around the restoration was reconstructed by using CT-Analyser V.1.14.4 (Bruker) and was visualized by using CTvol V2.2.3 (Bruker). The region of interest was set up along the cervical wall and coronal wall of each restoration, including their respective extensions at the axial wall (Fig. 1). The volume of leakage was measured by using CT-Analyser V.1.14.4 (Bruker).

\section{Statistics}

The means and standard deviations of the leakage
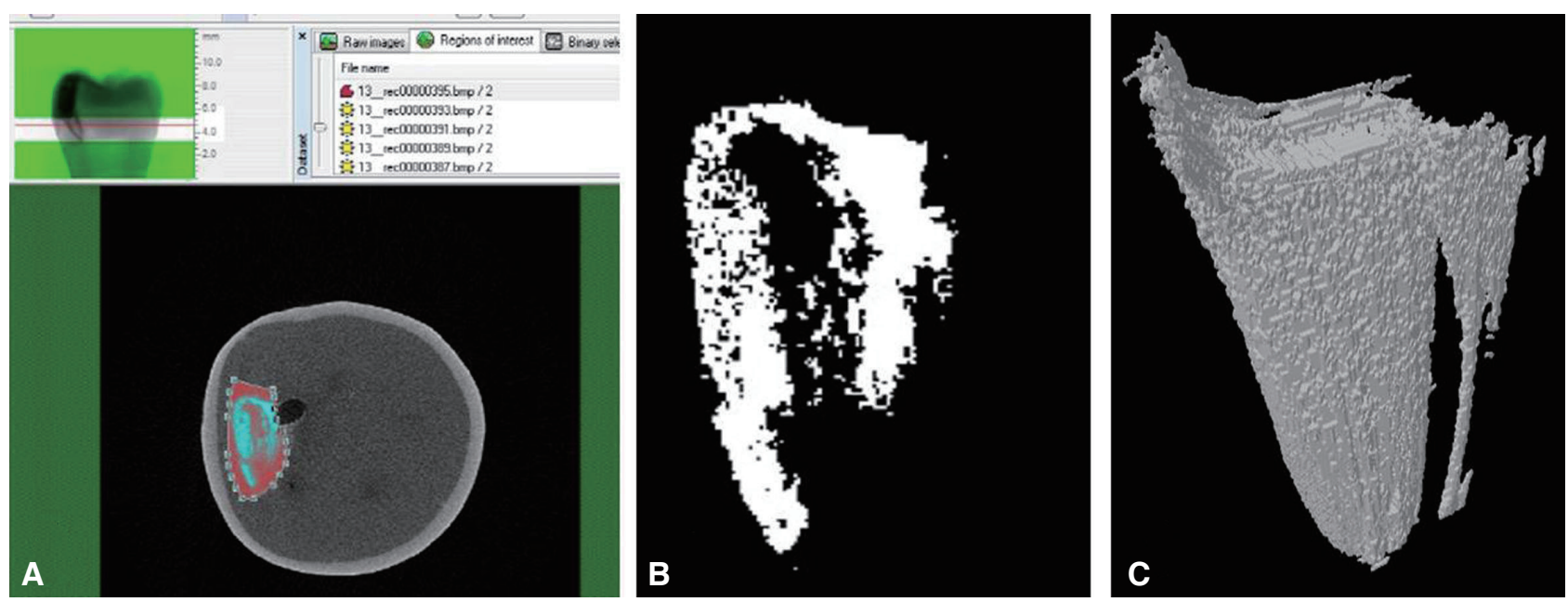

Fig. 1. Microleakage assessment. (A) The region of interest was set up along the cervical wall and coronal wall of each restoration, including their respective extensions at the axial wall. (B) 2D image of leakage around the restoration (C) 3D image of leakage around the restoration (reconstructed by using CT-Analyser). 
volumes were calculated. The data showed a nonnormal distribution; therefore, the mean differences in the microleakage were statistically analyzed by using the Mann-Whitney test for multiple pairwise comparisons of groups.

The statistical analysis was performed by using SPSS 20.0 for Windows (IBM Corp., New York, USA). The level of significance was set to $P<0.05$.

\section{Results}

The leakage volume around each restoration as measured by using micro-CT is shown in Table 4. Significant differences were observed between the light curing times, but no significant differences were found between the bulk fill flowable composite resins. Increasing the photoactivation time increased microleakage in all of the experimental groups. Groups 3 and 6 showed the highest mean microleakage values. Means and standard deviations (SD) in $\mathrm{mm}^{3}$ ( $\mathrm{n}$ $=5)$.
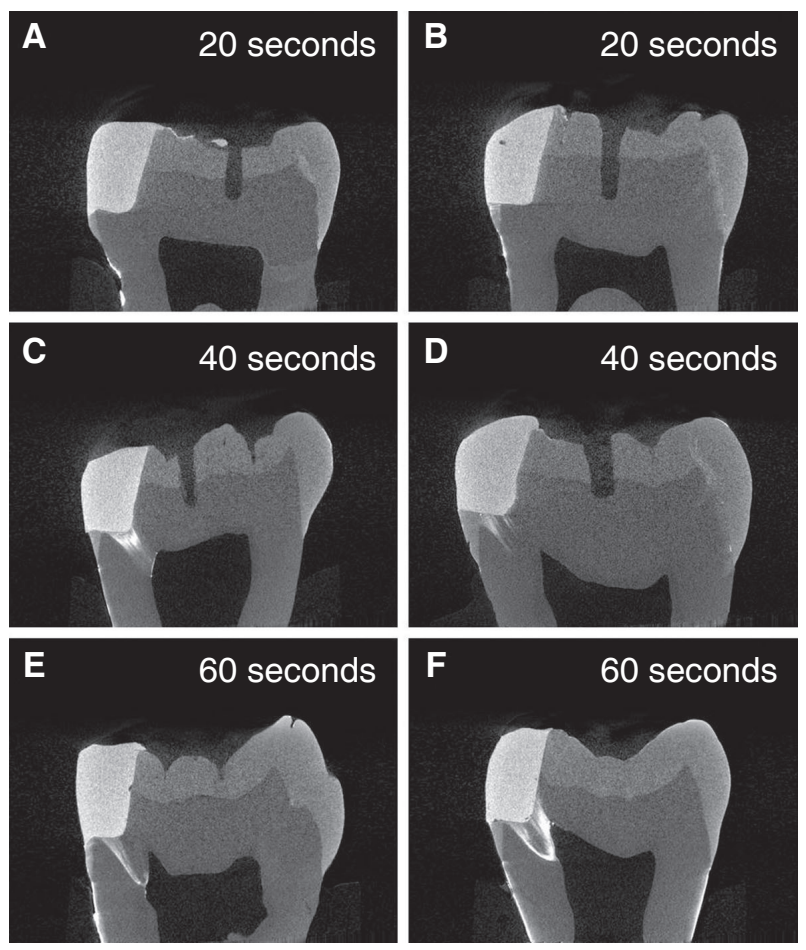

Fig. 2. Representative micro-CT images of SonicFill groups. (A) and (B): group 1, (C) and (D): group 2, (E) and $(F)$ : group 3.
The lowercase letters indicate significant differences at the 5\% significance level in the groups in the vertical columns.

The capital letter indicates no significant difference at the $5 \%$ significance level in the groups in the horizontal columns.

Representative images of each of the experimental groups are shown in Fig. 2 and 3. Silver nitrate infiltrated from the gap and was identifiable by white

Table 4. Marginal leakage in the experimental groups

\begin{tabular}{ccc}
\hline Group & \multicolumn{2}{c}{ Bulk fill composites } \\
\hline Curing time & SonicFill & SureFil SDR flow \\
20 seconds & $0.06(0.03)^{\mathrm{Aa}}$ & $0.03(0.05)^{\mathrm{Aa}}$ \\
40 seconds & $0.68(0.27)^{\mathrm{Ab}}$ & $0.54(0.52)^{\mathrm{Ab}}$ \\
60 seconds & $2.12(0.83)^{\mathrm{Ac}}$ & $1.95(0.90)^{\mathrm{Ac}}$ \\
\hline
\end{tabular}

Means and standard deviations (SD) in $\mathrm{mm}^{3}(\mathrm{n}=5)$.

The lowercase letters indicate significant differences at the $5 \%$ significance level in the groups in the vertical columns.

The capital letter indicates no significant difference at the 5\% significance level in the groups in the horizontal columns.
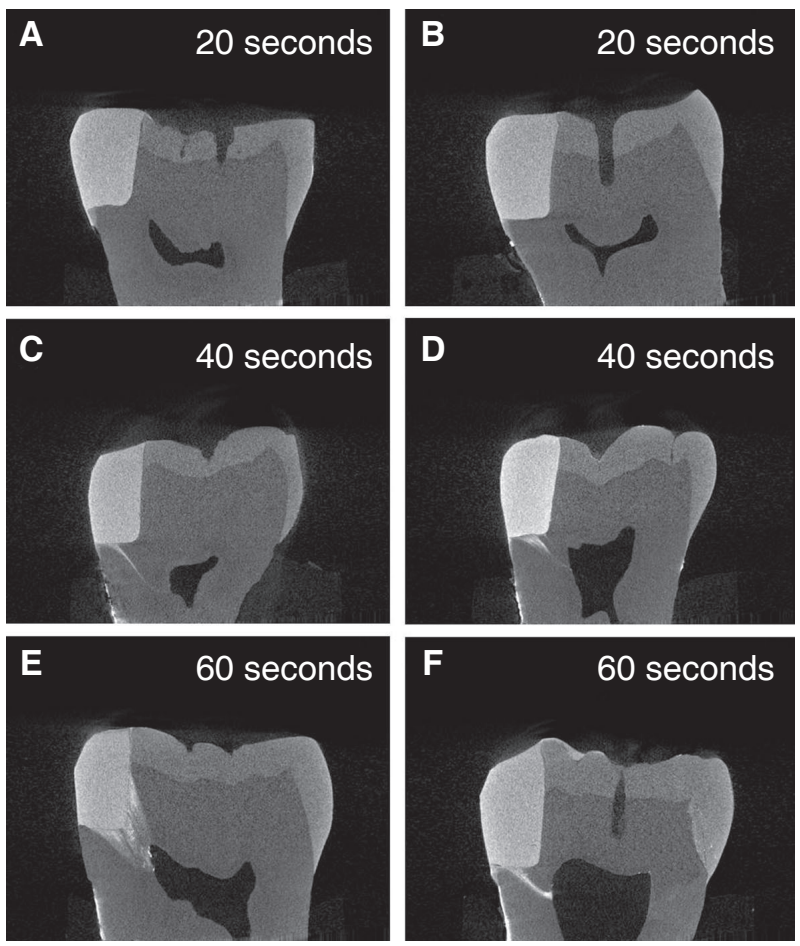

Fig. 3. Representative micro-CT images of SureFil SDR flow groups. (A) and (B): group 4, (C) and (D): group 5, (E) and $(\mathrm{F})$ : group 6 . 

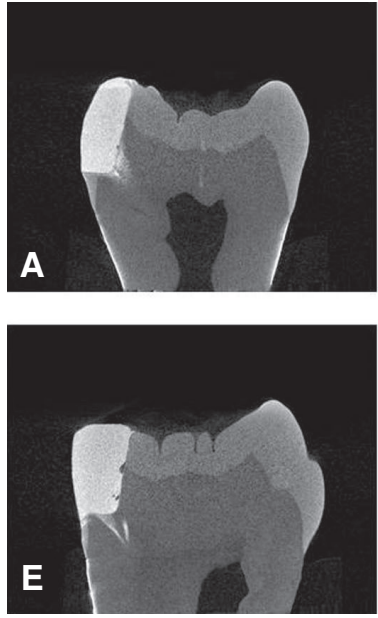

B
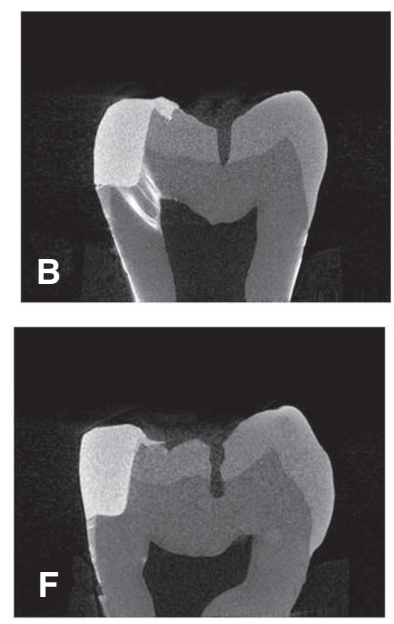
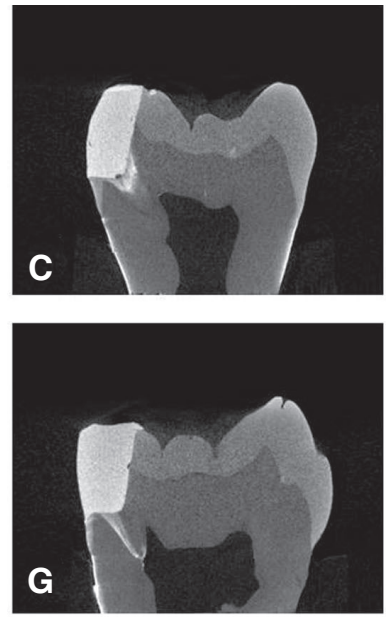
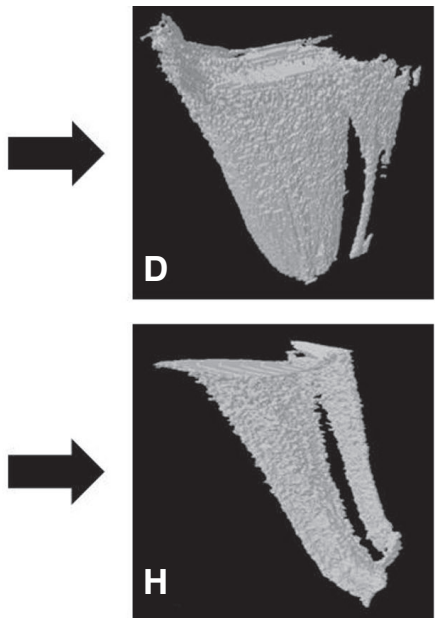

Fig. 4. Representative images of the mid-longitudinal sections and other sections of the restorations (Group 3). (A), (B), and $(C)$ : section images for 1 specimen, $(E),(F)$, and $(G)$ : section images for another specimen. $(B)$ and $(F)$ : images for the mid-longitudinal sections, $(A),(C),(E)$, and $(G)$ : images for the other sections. $(D)$ and $(H)$ : reconstructed 3D images of microleakage. (B) shows microleakage toward the pulp chamber, whereas (F) shows no microleakage.

spots or high-intensity clusters. In groups $2,3,5$ and 6 , the silver nitrate infiltrated into the dentinal tubules and penetrated toward the pulp chamber. As expected, most restorations had more leakage in the cervical region than in the coronal region in terms of both depth and area. In addition, some leakage extended to the axial wall from the cervical wall of the cavty.

Representative images for several sections are shown in Fig. 4. Although no microleakage of silver nitrate solution was observed in the mid-longitudinal sections of some specimens, leakage was detected in the other sections of the specimens.

\section{Discussion}

In this study, we found statistically significant differences between the curing time and microleakage values. Moreover, the mean microleakage values increased as photoactivation time increased.

The results of this study may be explained by the following 2 factors: 1) polymerization shrinkage stress and 2) polymer elastic modulus.

Higher radiant exposure induces greater stress because of contraction of the dental composites. ${ }^{20}$
In the case of lower radiant exposure, the reaction occurs more slowly and fewer polymer centers will form on the top surface. This slow reaction results in a polymeric structure that is more linear in the composite resins. ${ }^{21}$ Thus, lower irradiance will delay the increase in the viscosity of the resin composite during polymerization and decrease the polymerization stress.

Further, the quality of the polymer formed after photocuring may influence the microleakage values. Linear polymers with low cross-linking density have a low elastic modulus, and this is associated with relieving stress from contraction. Therefore, a lower elastic modulus may be related to lower microleakage values. $^{22}$

A prominent increase in marginal leakage was observed as the photoactivation time increased, and the relationship between the exposure time and marginal leakage was strong. Visvanathan et al. reported that the mechanical properties of different curing regimens were similar, but the shrinkage stress differed significantly. ${ }^{18}$ Bouschlicher et al. also showed that the exposure time was important for determining the polymerization shrinkage force. ${ }^{23}$ Similarly, the use of a single curing method (light exposure for 20 seconds 
with a $0-\mathrm{mm}$ distance to the resin) with both the SonicFill and SureFil SDR flow induced a cure degree of $4 \mathrm{~mm} .^{24}$ Therefore, light irradiation for a 20 -second exposure period appears to produce appropriate polymerization as well as minimal microleakage.

In our study, 2 bulk fill flowable composite materials were used for evaluating marginal leakage. For these composite resins, the increased depth of cure might be due to the increased translucency, as well as the photoinitiator systems and modified monomers. ${ }^{11}$ SonicFill and SureFil SDR flow increase translucency because of the large filler size. In addition, the manufacturer states that the polymerization modulator of the SureFil SDR flow synergistically interacts with the camphoroquinone photoinitiator, thereby accelerating the polymerization process. ${ }^{25}$ Bulk fill composites with greater translucency can cure outside of the indirect light path because of internal scattering, so it may be less important how the light guide is positioned and oriented with these composites. ${ }^{26}$

For the study design, we used 3 different curing times (20, 40, and 60 seconds). The manufacturer recommends that the SonicFill and SureFil SDR flow can be placed in a 4-mm bulk increment with a light exposure of 20 seconds. Several studies reported that the SureFil SDR flow properly cured in 4- $\mathrm{mm}$ increments for the recommended curing time (20 seconds), but the SonicFill failed to meet the curing requirements under these conditions. ${ }^{27-29}$ Ilie and Stark demonstrated that 3 curing regimes ( 0 - $\mathrm{mm}$ exposure distance, standard power mode, and 20- or 40-second exposures; or 7-mm exposure distance, standard power mode, and 40 seconds) induced depth of cure values of $4 \mathrm{~mm}$ or larger with the SonicFill. ${ }^{24}$

In our study, we used micro-CT to assess marginal leakage. Micro-CT is non-destructive method that enables the visualization of continuous images and detection of the deepest marginal leakage point. ${ }^{30}$ Furthermore, the length, area, and volume can be measured quantitatively by using analysis software. ${ }^{31}$ A previous study demonstrated that micro-CT analysis was consistent with stereomicroscopy in $92.5 \%$ of observations when assessing with silver nitrate staining. ${ }^{32}$

As shown in Fig. 4, no microleakage of silver ni- trate solution occurred in the mid-longitudinal sections of some specimens, whereas microleakage did occur in the other sections of specimens. The leakage measured for a selected area did not represent the entire area. Detecting all of the leakage around the restoration for $3 \mathrm{D}$ reconstruction was possible with micro-CT. The limitations of the conventional sectioning method are that the interfacial staining is viewed on a limited number of tooth slices, and the cutting procedure inevitably involves damage to the specimens. In addition, the sectioning method is time consuming and prevents further use of the specimen. ${ }^{33}$

For the micro-CT method, the radiographic contrast agents used to display leakage should be highly radiopaque in relation to the restorative material and tooth structure. The atomic number of silver is much higher than that of the elements that exist in tooth hard tissues and composite resin fillings. Thus, silver is capable of presenting a good radiopaque contrast when it is dense. ${ }^{31}$ Further, the silver nitrate method of measuring microleakage is an acceptable technique because the silver ion is extremely small $(0.059$ $\mathrm{nm})$ compared to the size of a typical bacterium (0.5 - $1.0 \mu \mathrm{m}$ ), thereby making it more penetrative. ${ }^{34}$ The silver ion could be trapped in the dentinal tubules during the course of infiltration.

However, the drawback of micro-CT is lower sensitivity when identifying leakage in the enamel. Dentin is less radiopaque than enamel because of its lower hydroxyapatite content, so it provides a good contrast to silver leakage. Therefore, some peripheral areas of silver leakage near the enamel structure cannot be detected because of their lower radiopaque value, which results in a $3 \mathrm{D}$ image of leakage that is smaller than the actual leakage. ${ }^{32}$

The current study had several limitations. First, our study conditions could not perfectly imitate actual condition. Numerous factors such as the interference of matrix bands, oral anatomy, limited opening by the patient, curing light design, and variable light curing technique by the dentist or assistant will affect the quantity of the delivered light to the composite resin. Such clinical limitations may require consideration of a greater curing time to achieve ideal photo- 
polymerization. Second, the sample size for each test was small. Greater statistical discrimination among the factors could have been identified if the sample size had been larger.

\section{Conclusion}

Within the limitations of this study, we conclude that increasing the photoactivation time is the factors that may increase the marginal microleakage of the bulk fill flowable composite resins, and no significant differences in marginal leakage were found between SonicFill and SureFil SDR flow. Further, micro-CT can nondestructively detect the leakage around the resin composite restoration in three dimensions.

\section{ORCID}

Eun-Ji Kim http://orcid.org/0000-0003-0514-2406

Kyu-Bok Lee http://orcid.org/0000-0002-1838-7229

Myoung Uk Jin http://orcid.org/0000-0001-9263-047X

\section{References}

1. Mahmound SH, Al-Wakeel Eel S. Marginal adaptation of ormocer-, silorane-, and methacrylate-based composite restorative systems bonded to dentin cavities after water storage. Quintessence Int 2011; 42:e131-9.

2. Czasch P, Ilie N. In vitro comparison of mechanical properties and degree of cure of bulk fill composites. Clin Oral Investig 2013;17:227-35.

3. Ilie N, Hickel R. Investigations on a methacrylatebased flowable composite based on the SDR technology. Dent Mater 2011;27:348-55.

4. El-Damanhoury H, Platt J. Polymerization shrinkage stress kinetic and related properties of bulk-fill resin composites. Oper Dent 2014;39:374-82.

5. Moorthy A, Hogg CH, Dowling AH, Grufferty BF, Benetti AR, Fleming GJ. Cuspal deflection and microleakage in premolar teeth restored with bulkfill flowable resin-based composite base materials. J Dent 2012;40:500-5.

6. El-Safty S, Silikas N, Watts DC. Creep deformation of restorative resin-composites intended for bulk- fill placement. Dent Mater 2012;28:928-35.

7. Naoum SJ, Ellakwa A, Morgan L, White K, Martin FE, Lee IB. Polymerization profile analysis of resin composite dental restorative materials in real time. J Dent 2012;40:64-70.

8. Ilie N, Stark K. Curing behaviour of high-viscosity bulk-fill composites. J Dent 2014;42:977-85.

9. Alrahlah A, Silikas N, Watts DC. Post-cure depth of cure of bulk fill dental resin-composites. Dent Mater 2014;30:149-54.

10. Ilie N, Keßler A, Durner J. Influence of various irradiation processes on the mechanical properties and polymerization kinetics of bulk-fill resin based composites. J Dent 2013;41:695-702.

11. Flury S, Hayoz S, Peutzfeldt A, Hüsler J, Lussi A. Depth of cure of resin composites: is the ISO 4049 method suitable for bulk fill materials? Dent Mater 2012;28:521-8.

12. Abbas G, Fleming GJ, Harrington E, Shortall AC, Burke FJ. Cuspal movement and microleakage in premolar teeth restored with a packable composite cured in bulk or in increments. J Dent 2003;31:43744.

13. Tiba A, Zeller GG, Estrich CG, Hong A. A laboratory evaluation of bulk-fill versus traditional multiincrement-fill resin-based composites. J Am Dent Assoc 2013;144:1182-3.

14. Watts DC. Reaction kinetics and mechanics in photo-polymerised networks. Dent Mater 2005;21:2735.

15. Yoon TH, Lee YK, Lim BS, Kim CW. Degree of polymerization of resin composites by different light sources. J Oral Rehabil 2002;29:1165-73.

16. Price RB, Ehrnford L, Andreous P, Felix CA. Comparison of quartz-tungsten-halogen, light-emitting diode, and plasma arc curing lights. J Adhes Dent 2003;5:193-207.

17. Rueggeberg F. Contemporary issues in photocuring. Compend Contin Educ Dent Suppl 1999;25:S4S15.

18. Visvanathan A, Ilie N, Hickel R, Kunzelmann KH. The influence of curing times and light curing methods on the polymerization shrinkage stress of a shrinkage-optimized composite with hybrid-type prepolymer fillers. Dent Mater 2007;23:777-84. 
19. Dewaele M, Asmussen E, Devaux J, Leloup G. Class II restorations: influence of a liner with rubbery qualities on the occurrence and size of cervical gaps. Eur J Oral Sci 2006;114:535-541.

20. Feilzer AJ, Dooren LH, de GEE AJ, Davidson CL. Influence of light intensity on polymerization shrinkage and integrity of restoration-cavity interface. Eur J Oral Sci 1995;103:322-6.

21. Atai M, Watts DC. A new kinetic model for the photopolymerization shrinkage-strain of dental composites and resin monomers. Dent Mater 2006; 22:785-91.

22. Pongprueksa P, Kuphasuk W, Senawongse P. The elastic moduli across various types of resin/dentin interfaces. Dent Mater 2008;24:1102-6.

23. Bouschlicher MR, Rueggeberg FA, Boyer DB. Effect of stepped light intensity on polymerization force and conversion in a photoactivated composite. J Esthet Dent 2000;12:23-32.

24. Ilie N, Stark K. Curing behaviour of high-viscosity bulk-fill composites. J Dent 2014;42:977-85.

25. Ilie N, Bucuta S, Draenert M. Bulk-fill resin-based composites: an in vitro assessment of their mechanical performance. Oper Dent 2013;38:618-25.

26. Li X, Pongprueksa P, Van Meerbeek B, De Munck J. Curing profile of bulk-fill resin-based composites. J Dent 2015;43:664-72.

27. Garcia D, Yaman P, Dennison J, Neiva G. Polymerization shrinkage and depth of cure of bulk fill flowable composite resins. Oper Dent 2014;39:4418.

28. Benetti AR, Havndrup-Pedersen C, Honoré D, Pedersen MK, Pallesen U. Bulk-fill resin composites: polymerization contraction, depth of cure, and gap formation. Oper Dent 2015;40:190-200.

29. Jang JH, Park SH, Hwang IN. Polymerization shrinkage and depth of cure of bulk-fill resin composites and highly filled flowable resin. Oper Dent 2015;40:172-80.

30. Eden E, Topaloglu-AK A, Cuijpers V, Frenchen JE. Micro-CT for measuring marginal leakage of Class II resin composite restorations in primary molars prepared in vivo. Am J Dent 2008;21:393-7.

31. Zhao XY, Li SB, Gu LJ, Li Y. Detection of marginal leakage of Class $\mathrm{V}$ restorations in vitro by microcomputed tomography. Oper Dent 2014;39:174-80.

32. Chen X, Cuijpers VM, Fan MW, Frencken JE. Validation of micro-CT against the section method regarding the assessment of marginal leakage of sealant. Aust Dent J 2012;57:196-9.

33. Raskin A, Tassery H, D'Hoore W, Gonthier S, Vreven J, Degrange M, Déjou J. Influence of the number of sections on reliability of in vitro microleakage evaluations. Am J Dent 2003;16:207-10.

34. Abdalla AI, Davidson CL. Comparison of the marginal integrity of in vivo and in vitro Class II composite restorations. J Dent 1993;21:158-62. 


\section{Bulk fill 유동성 복합레진의 변연 누출에서 다른 중합시간의 영향에 대해 마이크로시티를 이용한 평가}

김은지 ${ }^{1}$, 이규복 ${ }^{2}$, 진명욱 ${ }^{*}$

${ }^{1}$ 경북대학교 치의학전문대학원 치과보존학교실

${ }^{2}$ 경북대학교 치의학전문대학원 치과보철학교실, 경북대학교 첨단치과의료기기개발연구소

목적: 중합 시간이 bulk fill 유동성 복합레진의 미세누출에 미치는 영향을 마이크로시티를 이용하여 평가하고자 하였다. 연구 재료 및 방법: 30 개의 발거된 인간 대구치에 변형된 2급 와동인 vertical slot cavity를 형성하였다. SonicFill과 SureFil SDR flow을 단일 충전하였으며, 다른 중합시간(20, 40, 60초)으로 광중합 하였다. 모든 표본은 5000번의 thermal cycle 을 시행하였다. 치아는 silver nitrate 용액에 24시간 동안 침전 후 8시간 동안 현상액에 침전하였다. 마이크로시티를 사용 하여 시편을 촬영 후 침투된 silver nitrate solution을 3차원적으로 재건하여 그 부피를 측정하였다. 변연 누출 결과값의 통계 처리는 Mann-Whitney test를 사용하였다.

결과: 광중합 시간의 증가는 두 bulk fill 유동성 복합레진에서 변연 누출을 증가시켰다. 두 복합레진 사이 유의한 차이는 없었다.

결론: 중합 시간은 bulk fill 유동성 복합레진의 변연 누출을 증가시킬 수 있는 요인이었다. 또한 마이크로시티를 통해 레 진-치아 계면에서 변연 누출의 양을 비파괴적 방법으로 3차원적으로 재건하여 측정할 수 있었다.

(구강회복응용과학지 2016;32(3): 184-93)

주요어: 변연 누출; bulk fill; 중합 시간; 마이크로시티

*교신저자: 진명욱

(41940)대구광역시 중구 달구벌대로 2177 경북대학교 치의학전문대학원 치과보존학교실

Tel: 053-600-7623 | Fax: 053-426-8958 | E-mail: musljin@knu.ac. kr

접수일: 2016년 8월 22일 | 수정일: 2016년 8월 22일 | 채택일: 2016년 9월 13일 